5.

\title{
Cancers attributable to dietary factors in the UK in 2010
}

\section{Meat consumption}

\section{DM Parkin ${ }^{*, I}$}

'Centre for Cancer Prevention, Wolfson Institute of Preventive Medicine, Queen Mary University of London, Charterhouse Square, London ECIM 6BQ, UK

British Journal of Cancer (20 I I) 105, S24-S26; doi: 10.1038/bjc.20I I.478 www.bjcancer.com

(C) 20II Cancer Research UK

The current consensus based on several published meta-analyses is that consumption of red meat (all fresh, minced, and frozen beef, veal, pork and lamb), especially processed meat (any meat preserved by methods other than freezing, including marinating, smoking, salting, air-drying or heating (includes ham, bacon, sausages, pate and tinned meat)), is associated with an increased risk of bowel cancer (Department of Health, 1998; WHO/FAO, 2003; WCRF, 2007). Sandhu et al (2001) observed significant positive associations with all meat and red meat (an increased risk of around $15 \%$ per $100 \mathrm{~g}$ per day intake of red meat), and a stronger increase for processed meat (49\% risk increase for a $25 \mathrm{-g}$ per day serving). Norat et al (2002) found a significant increase in risk for colorectal cancer with higher consumption of red meat (1.24 per $120 \mathrm{~g}$ per day) and processed meat (1.36 per $30 \mathrm{~g}$ per day). Larsson and Wolk (2006) considered 15 prospective studies, and found a relative risk of 1.28 for an increase of $120 \mathrm{~g}$ per day intake of red meat and 1.09 for an increase of $30 \mathrm{~g}$ per day intake of processed meat. Consumption of red meat and processed meat was positively associated with the risk of both colon and rectal cancer, although the association with red meat appeared to be stronger for rectal cancer.

There are no dietary guidelines concerning recommended levels of consumption of red and processed meat; as for alcohol, it is assumed that 'less is better' and that there is no threshold below which consumption presents no risk. In this section, we assume that the optimum (or target) is zero consumption. Currently, about $10 \%$ of the adult population are vegetarian, or consume only fish and poultry products (DEFRA, 2007).

\section{METHODS}

The relative risk of meat consumption for colorectal cancer is taken from the WCRF report (2007), and is based on the effect of red meat in a meta-analysis of three prospective studies (1.29 per $100 \mathrm{~g}$ red meat per day). Under the assumption that the increase in risk is a logarithmic function of intake of meat, the risk is increased by 0.0025 for each gram of meat consumed. The effect of processed meat, based on five studies, was 1.21 per $50 \mathrm{~g}$ per day (the excess risk corresponds to 0.0038 per gram).

*Correspondence: Professor DM Parkin; E-mail: d.m.parkin@qmul.ac.uk
The latent period, or interval between 'exposure' to meat and the increased risk of colorectal cancer, is not known. In the cohort studies included in the meta-analyses by WCRF (2007), the mean duration of follow-up was 8.9 years. In studies contributing to the meta-analysis by Larsson and Wolk (2006), the mean duration of follow-up (when this was given) was 8.7 years. We chose to assume a mean latency of 10 years, and estimate the effects on cancers occurring in 2010 from meat consumption in 2000 .

Information on consumption of meat in the UK is available for 2000-2001 from the National Diet and Nutrition Survey (Food Standards Agency, 2002) as mean consumption, in grams of different types of meat per week, by age group and sex. The relevant data are shown in Table 1.

The population distribution of protein consumption, in grams per day, by age group and sex, is available from the National Diet and Nutrition Survey (Volume 2, Table 3.1; Food Standards Agency, 2003). This was converted to grams of meat per day, based on the average intake of meat (Table 1) and protein (NDNS Volume 2, Table 3.4) in each age-sex group.

The estimate for 2000 is shown in Table 2 (as the percentage of the population in different age-sex groups consuming specified amounts of red and processed meat), and in Figure 1 as the cumulative frequency (percentage) of the population in each age-sex group at different consumption levels.

The relative risk of meat consumption for each of the $x$ consumption categories shown in Table 2 was calculated according to the following formula:

$$
\mathrm{RR}_{x}=\exp \left(R_{g} \times G_{x}\right)
$$

where $R_{g}$ is the increase in risk of colon cancer per gram of meat $(0.0025)$ and $G_{x}$ is the consumption of meat in gram per day in category $x$.

Population-attributable fractions (PAFs) were calculated for each sex-age group according to the following formula:

$$
\mathrm{PAF}=\frac{\Sigma\left(p_{x} \times \mathrm{ERR}_{x}\right)}{1+\Sigma\left(p_{x} \times \mathrm{ERR}_{x}\right)}
$$

where $p_{x}$ is the proportion of population in consumption category $x$ and $\operatorname{ERR}_{x}$ the excess relative risk $\left(\mathrm{RR}_{x}-1\right)$ in consumption category $x$. 
Table I Total quantities of meat consumed by age of respondent, including non-consumers (Great Britain, 2000-200 I)

Grams per day consumed, by age (years)

\begin{tabular}{|c|c|c|c|c|c|c|c|c|c|c|}
\hline Meat & \multicolumn{5}{|c|}{ Men } & \multicolumn{5}{|c|}{ Women } \\
\hline $\begin{array}{l}\text { Red meat }{ }^{\mathrm{a}} \text { (including liver) } \\
\text { Processed meat } \\
\text { Red (including processed) } \\
\text { All meat products }{ }^{\mathrm{a}}\end{array}$ & $\begin{array}{r}63 \\
63 \\
125 \\
144\end{array}$ & $\begin{array}{r}72 \\
50 \\
122 \\
142\end{array}$ & $\begin{array}{r}74 \\
43 \\
118 \\
137\end{array}$ & $\begin{array}{r}77 \\
35 \\
111 \\
133\end{array}$ & $\begin{array}{r}73 \\
45 \\
118 \\
138\end{array}$ & $\begin{array}{l}45 \\
32 \\
77 \\
86\end{array}$ & $\begin{array}{l}37 \\
24 \\
62 \\
70\end{array}$ & $\begin{array}{l}50 \\
21 \\
71 \\
81\end{array}$ & $\begin{array}{l}52 \\
19 \\
71 \\
80\end{array}$ & $\begin{array}{l}47 \\
23 \\
69 \\
78\end{array}$ \\
\hline
\end{tabular}

${ }^{a}$ Excludes poultry. ${ }^{\mathrm{b}}$ Bacon, ham, sausages, burgers, kebabs.

Table 2 Distribution of meat (red and processed) consumption by age group and sex, grams

\begin{tabular}{|c|c|c|c|c|c|c|c|c|c|c|}
\hline \multirow[b]{3}{*}{$\begin{array}{l}\text { Consumption } \\
\text { category }\end{array}$} & \multicolumn{10}{|c|}{$\begin{array}{c}\text { Consumption of red and processed meat } \\
\text { by age group (years) }\end{array}$} \\
\hline & \multicolumn{2}{|c|}{$19-24$} & \multicolumn{2}{|c|}{$25-34$} & \multicolumn{2}{|c|}{$35-49$} & \multicolumn{2}{|c|}{$50-64$} & \multicolumn{2}{|c|}{ All ages } \\
\hline & $\begin{array}{l}\text { grams } \\
\text { per day }\end{array}$ & $\%$ & $\begin{array}{l}\text { grams } \\
\text { per day }\end{array}$ & $\%$ & $\begin{array}{l}\text { grams } \\
\text { per day }\end{array}$ & $\%$ & $\begin{array}{l}\text { grams } \\
\text { per day }\end{array}$ & $\%$ & $\begin{array}{l}\text { grams } \\
\text { per day }\end{array}$ & $\%$ \\
\hline \multicolumn{11}{|l|}{ Men } \\
\hline 1 & 0 & 6 & 0 & 0 & 0 & 2 & 0 & 3 & 0 & 2 \\
\hline 2 & 79 & 6 & 66 & 2 & 64 & 4 & 62 & 3 & 66 & 4 \\
\hline 3 & 88 & 0 & 74 & 3 & 71 & I & 68 & I & 73 & I \\
\hline 4 & 97 & I | & 81 & 14 & 79 & 6 & 76 & 7 & 81 & 9 \\
\hline 5 & 113 & 22 & 95 & 14 & 91 & 9 & 88 & 14 & 94 & 14 \\
\hline 6 & 129 & 19 & 108 & 16 & 105 & 19 & 100 & 19 & 107 & 18 \\
\hline 7 & 145 & 19 & 122 & 21 & 118 & 23 & 113 & 13 & 120 & 19 \\
\hline 8 & 161 & 9 & 135 & 13 & $13 \mid$ & 14 & 125 & 16 & 134 & 13 \\
\hline 9 & 177 & 7 & 149 & 8 & 144 & 8 & 138 & 8 & 147 & 9 \\
\hline 10 & 193 & 1 & 162 & 3 & 157 & 6 & $15 \mid$ & 10 & $16 \mid$ & 5 \\
\hline 11 & 217 & 0 & 182 & 6 & 176 & 8 & 169 & 6 & 181 & 6 \\
\hline $\begin{array}{l}\text { Mean gram } \\
\text { per day }\end{array}$ & 125 & & 122 & & 118 & & 111 & & 118 & \\
\hline \multicolumn{11}{|l|}{ Women } \\
\hline I & 0 & 7 & 0 & 7 & 0 & 4 & 0 & 2 & 0 & 4 \\
\hline 2 & 52 & 9 & 42 & 13 & 44 & 6 & 42 & 6 & 44 & 9 \\
\hline 3 & 59 & 4 & 48 & I & 50 & 2 & 49 & I & 50 & I \\
\hline 4 & 66 & 17 & 54 & 22 & 56 & 15 & 54 & | | & 55 & 16 \\
\hline 5 & 77 & 28 & 63 & 26 & 65 & 21 & 63 & 25 & 65 & 24 \\
\hline 6 & 90 & 19 & 74 & 17 & 76 & 26 & 74 & 25 & 76 & 23 \\
\hline 7 & 103 & 9 & 84 & 9 & 87 & 16 & 84 & 16 & 87 & 13 \\
\hline 8 & 116 & 6 & 95 & 3 & 98 & 6 & 95 & 10 & 98 & 7 \\
\hline 9 & 129 & 1 & 105 & 1 & 109 & 3 & 106 & 4 & 109 & 2 \\
\hline 10 & 148 & 0 & 121 & I & 125 & 1 & 121 & 0 & 125 & I \\
\hline $\begin{array}{l}\text { Mean gram } \\
\text { per day }\end{array}$ & 77 & & 62 & & 71 & & 71 & & 69 & \\
\hline
\end{tabular}

\section{RESULTS}

Table 3 shows PAFs of colorectal cancer resulting from meat consumption in 2000-2001, and the estimated number of cases 'caused' in 2010. The final three columns show the excess numbers of cases of colorectal cancer caused by meat consumption expressed as a fraction of the total burden of (incident) cancer. The estimate is $3.5 \%$ cancers in men and $1.9 \%$ in women, or $2.7 \%$ of cancers overall.

\section{DISCUSSION}

The association between consumption of red and processed meat and the risk of cancer of the colon and rectum is now well established. Although the risk for processed meat products (such as ham, bacon, sausages, pate and tinned meat) is greater than that for fresh meat, in this analysis we have considered both together,

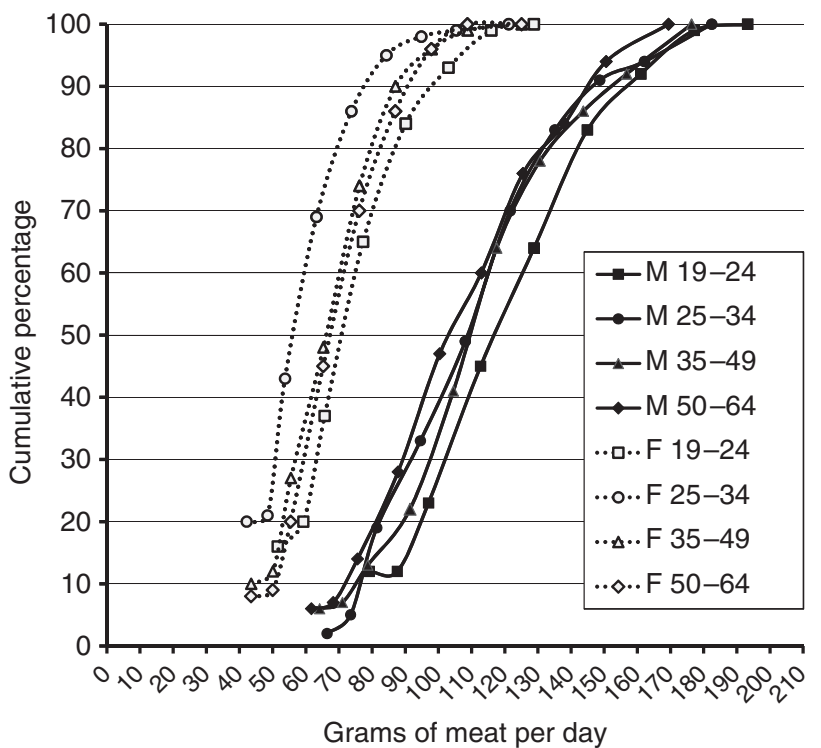

Figure I Estimated consumption of red and processed meat, by age group and sex, expressed as grams per day.

partly because separate estimates of intake (by age group and sex) would be difficult, and partly because it would not affect the overall estimate, which is concerned with the proportion of colorectal cancer related to any meat consumption (i.e., over and above a diet including poultry and fish, as sources of animal protein).

The estimation of attributable fraction is against a baseline of a diet that would contain no red meat, and is based on the relative risks of consumption of red meat, according to the review by WCRF (2007). The values for red meat consumption (1.29 per $100 \mathrm{~g}$ per day) are rather higher than those in the more recent meta-analysis of Larsson and Wolk (1.29 per $120 \mathrm{~g}$ per day, when adjusted for BMI, physical activity, smoking, energy intake and so on). These values would have given a total of $18 \%$ of colon cancers due to consumption of red meat (rather than $21.1 \%$, as in Table 3).

Norat et al (2002) estimated the proportion of colorectal cancer risk attributable to current (1995) red meat consumption in North and Central Europe as $7.8 \%$ in men and $5.8 \%$ in women, much lower than the estimated percentages in the UK, but estimated per caput red meat consumption of this population ( $47.3 \mathrm{~g}$ per day in men and $35 \mathrm{~g}$ per day in women) was around one-half of that in the UK in 2000 (Table 1). WCRF (2009), based on the relative risks from the EPIC study (Norat et al, 2005; 1.49 per $100 \mathrm{~g}$ red meat, 1.70 per $100 \mathrm{~g}$ processed meat), estimated that $15 \%$ of colorectal cancer in the UK in 2002 was due to consumption in excess of $10 \mathrm{~g}$ per day of red meat and $10 \mathrm{~g}$ per day of processed meat.

Several other cancers have been linked to consumption of red or processed meat. However, at the time of the review by WCRF 
Table 3 Colorectal cancer diagnosed in 2010, attributable to meat consumption in 2000-200 I

\begin{tabular}{|c|c|c|c|c|c|c|c|c|}
\hline \multicolumn{2}{|c|}{ Age (years) } & \multicolumn{4}{|c|}{ Colon-rectum } & \multicolumn{3}{|c|}{ All cancers ${ }^{a}$} \\
\hline At exposure & $\begin{array}{c}\text { At } \\
\text { outcome }\end{array}$ & PAF & $\begin{array}{l}\text { Observed } \\
\text { cases }\end{array}$ & $\begin{array}{c}\text { Excess attributable } \\
\text { cases }\end{array}$ & PAF (\%) & $\begin{array}{l}\text { Observed } \\
\text { cases }\end{array}$ & $\begin{array}{c}\text { Excess attributable } \\
\text { cases }\end{array}$ & PAF (\%) \\
\hline \multicolumn{9}{|l|}{ Men } \\
\hline $19-24$ & $29-34$ & 0.27 & 92 & 24.8 & 26.9 & 1333 & 24.8 & 1.9 \\
\hline $25-34$ & $35-44$ & 0.26 & 397 & 102.5 & 25.8 & 4124 & 102.5 & 2.5 \\
\hline $35-49$ & $45-59$ & 0.26 & 2921 & 756.7 & 25.9 & 22388 & 756.7 & 3.4 \\
\hline $50-64$ & $\geqslant 60$ & 0.25 & 18643 & 4611.3 & 24.7 & 128192 & 4611.3 & 3.6 \\
\hline All ages & & & 22127 & 5495.3 & 24.8 & 158667 & 5495.3 & 3.5 \\
\hline \multicolumn{9}{|l|}{ Women } \\
\hline $19-24$ & $29-34$ & 0.17 & 97 & 16.9 & 17.5 & 2248 & 16.9 & 0.8 \\
\hline $25-34$ & $35-44$ & 0.14 & 402 & 57.0 & 14.2 & 8619 & 57.0 & 0.7 \\
\hline $35-49$ & $45-59$ & 0.16 & 2292 & 376.0 & 16.4 & 31631 & 376.0 & 1.2 \\
\hline $50-64$ & $\geqslant 60$ & 0.17 & 14926 & 2465.6 & 16.5 & 110403 & 2465.6 & 2.2 \\
\hline All ages & & & 17787 & 2915.5 & 16.4 & I55 584 & 2915.5 & 1.9 \\
\hline \multicolumn{9}{|l|}{ Persons } \\
\hline $19-24$ & $29-34$ & & 189 & 42 & 22.1 & 3582 & 42 & 1.2 \\
\hline $25-34$ & $35-44$ & & 799 & 160 & 20.0 & 12743 & 160 & 1.3 \\
\hline $35-49$ & $45-59$ & & 5213 & 1133 & 21.7 & 54019 & 1133 & 2.1 \\
\hline $50-64$ & $\geqslant 60$ & & 33569 & 7077 & 21.1 & 238595 & 7077 & 3.0 \\
\hline All ages & & & 39914 & 8411 & 21.1 & $31425 \mid$ & 8411 & 2.7 \\
\hline
\end{tabular}

Abbreviations: PAF = population-attributable fraction. ${ }^{a}$ Excluding non-melanoma skin cancer.

(2007), the evidence with respect to cancers of the oesophagus, lung, pancreas, endometrium, stomach and prostate was considered to be 'limited'. Only the associations between consumption of red and processed meat with an increased risk of colorectal cancer were considered to be 'convincing'.

\section{REFERENCES}

Department for Environment, Food and Rural Affairs (DEFRA) (Environment Statistics and Indicators Division) (2007) Report, Questionnaire and Data Tables Following Survey of Public Attitudes and Behaviours toward the Environment: Table 210, p 481. http://www.defra.gov.uk/environment/ statistics/pubatt/

Department of Health (1998) Nutritional Aspects of the Development of Cancer. Report of the Working Group on Diet and Cancer. Committee on Medical Aspects of Food Nutrition Policy. The Stationery Office: London

Food Standards Agency (2002) National Diet and Nutrition Survey: Adults Aged 19 to 64, Vol. 1. Types and Quantities of Foods Consumed. http:// www.food.gov.uk/multimedia/pdfs/ndnsprintedreport.pdf

Food Standards Agency (2003) National Diet and Nutrition Survey: Adults Aged 19 to 64, Vol. 2. Energy, Protein, Carbohydrate, Fat and Alcohol Intake. http://www.food.gov.uk/multimedia/pdfs/ndnsv2.pdf

Larsson SC, Wolk A (2006) Meat consumption and risk of colorectal cancer: a meta-analysis of prospective studies. Int J Cancer 119: $2657-2664$

Norat T, Bingham S, Ferrari P, Slimani N, Jenab M, Mazuir M, Overvad K, Olsen A, Tjønneland A, Clavel F, Boutron-Ruault MC, Kesse E, Boeing H, Bergmann MM, Nieters A, Linseisen J, Trichopoulou A, Trichopoulos D, Tountas Y, Berrino F, Palli D, Panico S, Tumino R, Vineis P, Buenode-Mesquita HB, Peeters PH, Engeset D, Lund E, Skeie G, Ardanaz E, González C, Navarro C, Quirós JR, Sanchez MJ, Berglund G, Mattisson I, Hallmans G, Palmqvist R, Day NE, Khaw KT, Key TJ, San Joaquin M, Hémon B, Saracci R, Kaaks R, Riboli E (2005) Meat, fish, and colorectal
See acknowledgements on page $\mathrm{Si}$.

\section{Conflict of interest}

The author declares no conflict of interest.

cancer risk: the European Prospective Investigation into cancer and nutrition. J Natl Cancer Inst 97: 906 -916

Norat T, Lukanova A, Ferrari P, Riboli E (2002) Meat consumption and colorectal cancer risk: dose-response meta-analysis of epidemiological studies. Int J Cancer 98: 241 - 256

Sandhu MS, White IR, McPherson K (2001) Systematic review of the prospective cohort studies on meat consumption and colorectal cancer risk: a meta-analytical approach. Cancer Epidemiol Biomarkers Prev 10: $439-446$

World Cancer Research Fund (WCRF)/American Institute for Cancer Research (AICR) (2009) Policy and Action for Cancer Prevention - Food, Nutrition and Physical Activity: A Global Perspective. American Institute for Cancer Research: Washington, DC

World Cancer Research Fund (WCRF) Panel (2007) Food, Nutrition, Physical Activity, and the Prevention of Cancer: A Global Perspective. World Cancer Research Fund: Washington, DC

World Health Organization (WHO)/Food and Agriculture Organization (FAO) (2003) Diet, Nutrition and The Prevention of Chronic Diseases: Report of a Joint WHO/FAO Expert Consultation. WHO Technical Report Series 916. WHO: Geneva

(c) (9) This work is licensed under the Creative Commons Attribution-NonCommercial-Share Alike 3.0 Unported License. To view a copy of this license, visit http://creativecommons org/licenses/by-nc-sa/3.0/ 